\title{
PENGARUH STRATEGI PENINGKATAN KINERJA KARYAWAN TERHADAP PENINGKATAN KUALITAS PRODUKSI TEH HIJAU DI PT. HK. WARINGIN PERKEBUNAN TEH GUNUNG KANCANA KAB.CIANJUR
}

\author{
Oleh: \\ Adang Suryana*) \\ Toni Suyono**) \\ Elma Nurhafidah Iskandar***) \\ Email : kangads472@gmail.com
}

\begin{abstract}
ABSTRAK
Sumber daya manusia merupakan salah satu faktor penting bagi sebuah organisasi, baik untuk institusi maupun perusahaan. Sumber daya manusia di sebuah organisasi merupakan sebagai penggerak, pemikir dan perencana untuk mencapai tujuan organisasi. Oleh karena itu, Sumber Daya Manusia (SDM) adalah aset atau modal penting bagi sebuah organisasi atau perusahaan. Tujuan penelitian ini untuk mengetahui pengaruh strategi peningkatan kinerja karyawan (Kinerja tenaga tetap) dan tenaga teknis (Kinerja tenaga lepas) di PT. HK. Waringin Perkebunan Teh Gunung Kancana Kab. Caianjur. Penelitian ini dilakukan di PT. HK Waringin Perkebunan Teh Gunung Kancana, yang terletak di Jln. Cilubang, Desa. Cibokor, Kecamatan Cibeber, Kabupaten Cianjur pada bulan Februari-Mei 2021. Populasi dan sampeling ini sebanyak 100 responden dengan menggunakan metode analisis uji validitas dan reabilitas. Berdasarkan uraian pada hasil penelitian, maka dapat ditarik kesimpulan bahwa variabel Kinerja Karyawan (X1) berpengaruuh Signifikan terhadap Variabel Kualitas Produksi (Y). Variabel Kinerja Tenaga Teknis (X2) tidak Berpengaruh signifikan terhadap Variabel Kualitas Produksi (Y). Variabel Kinerja Karyawan dan Kinerja Tenaga Teknis, berpengaruh signifikan secara simultan terhadap variabel Kualitas Produksi (Y).
\end{abstract}

Kata kunci : Strategi peningkatan, Kinerja karyawan, Kualitas produk.

\section{ABSTRACT}

Human resources are one of the important factors for an organization, both for institutions and companies. Human resources in an organization are as movers, thinkers and planners to achieve organizational goals. Therefore, buman resources (HR) are an important asset or capital for an organization or company. The purpose of this study was to determine the effect of strategies for improving employee performance (permanent employee performance) and technical personnel (freelancing performance) at PT. HK. Waringin Gunung Kancana Tea Plantation Kab. Caianjur. This research was conducted at PT. HK Waringin Gunung Kancana Tea Plantation, which is located on Jln. Cibubur, Village. Cibokor, Cibeber District, Cianjur Regency in February-May 2021. The population and sampling were 100 respondents using the validity and reliability test analysis method. Based on the description of the research results, it can be concluded that the Employee Performance variable (X1) bas a significant effect on the Production Quality Variable (Y). The Tecbnical Personnel Performance Variable (X2) has no significant effect on the Production Quality Variable (Y). Employee Performance V ariables and Technical Personnel Performance, have a significant simultaneous effect on the Production Quality variable $(Y)$.

Keywords: improvement strategy, employee performance, product quality.

*)Dosen Widyaiswara Madya PPPPTK Pertanian/BBPPMPV Pertanian.

**)Dosen Fakultas Sains Terapan UNSUR.

***)Alumni Fakultas Sains Terapan UNSUR.

\begin{tabular}{lrrr}
\hline PENGARUH & STRATEGI & PENINGKATAN & ADANG SURYANA, TONI SUYONO \\
KINERJA KARYAWAN & TERHADAP & dan ELMA NURHAFIDAH ISKANDAR \\
PENINGKATAN KUALITAS PRODUKSI TEH & \\
HIJAU DI & PT. & HK. & WARINGIN \\
PERKEBUNAN & TEH & GUNUNG & KANCANA \\
KAB.CIANJUR & &
\end{tabular}




\section{PENDAHULUAN}

Sumber daya manusia merupakan faktor yang sangat penting bagi sebuah organisasi, baik institusi maupun perusahaan. Sumber daya manusia di sebuah organisasi yaitu sebagai penggerak, pemikir dan perencana untuk mencapai tujuan organisasi, oleh karena itu sumber daya manusia (SDM) merupakan aset atau modal penting bagi sebuah organisasi atau perusahaan. Untuk mencapai kesuksesan perusahaan sebaiknya perusahaan memberikan perhatian tidak hanya tertuju pada tujuan para pekerja tetapi juga tujuan dari perusahaan itu sendiri, dengan kata lain dua tujuan harus terjadi secara simbiosis mutualisme agar Perusahaan serta Karyawan sama-sama saling di untungkan.

Menurut Edison (2016) Kinerja adalah hasil dari suatu proses yang mengacu dan diukur selama priode waktu tertentu berdasarkan ketentuan atau kesepakatan yang telah di tetapkan sebelumnya. Kinerja karyawan dapat ditingkatkan melalui peningkatan motivasi kerja dengan memberikan Insentif yang diberikan perusahaan kepada karyawan agar karyawan merasa semangat, meningkatnya kemauan dalam bekerja, serta ketelitian karyawan pada saat bekerja akan seperti fokus, dan disiplin pada saat bekerja. Jika perushaan menginginkan setiap karyawan dapat memberikan kontribusi positif terhadap pencapaian tujuan perusahaan untuk meningkatkan Produktivitas dan Kualitas dalam Produksi maka pembagian motivasi merupakan hal yang sangat penting untuk di perhatikan.

Produktivitas adalah bagaimana menghasilkan atau meningkatkan hasil barang dan jasa setinggi mungkin dengan memanfaatkan sumber daya secara efisien. banyak faktor yang mempengaruhi produktifitas kerja, baik yang berhubungan dengan tenaga kerja maupun yang berhubungan dengan lingkungan perusahaan dan kebijaksanaan pemerintah secara keseluruhan Peningkatan produktifitas di pengaruhi oleh beberapa faktor antara lain sikap kerja seperti : Kesediaan untuk bekerja secara bergiliran (shift work), Tingkat ketrampilan yang di tentukan oleh pendidikan latihan dalam manajemen, Hubungan antara tenaga kerja dan pimpinan organisisi, Manajemen produktifitas, Efisiensi tenaga kerja, Sedarmayanti, (2017). Produktivitas kerja karyawan dapat dipengaruhi oleh beberapa faktor yaitu faktor pendidikan dan faktor kesempatan berprestasi, untuk itu agar produktivitas kerja karyawan dapat selalu dijaga perusahaan perlu memperhatikan faktor tersebut.

Dalam pencapaian tujuan perusahaan melalui produktivitas kinerja karyawan yang tinggi dibutuhkan pihak pimpinan perusahaan yang memacu semangat kerja dibutuhkan dukungan semangat kerja karyawan antara lain melalui perhatian yang tepat, pemenuhan kebutuhan karyawan dan pemberian penghargaan kinerja, perhatian di harapkan dapat memberikan kerja sama dan tanggung jawab dalam bekerja upaya yang ditempuh oleh perusahaan dalam mengembangkan produktivitas teh hijau dengan melakukan kerja sama yang lebih antar Pimpinan dan Karyawan

\begin{tabular}{lrrr}
\hline PENGARUH & STRATEGI & PENINGKATAN & ADANG SURYANA, TONI SUYONO \\
KINERJA KARYAWAN & TERHADAP & dan ELMA NURHAFIDAH ISKANDAR \\
PENINGKATAN KUALITAS PRODUKSI TEH & \\
HIJAU DI & PT. & HK. & WARINGIN \\
PERKEBUNAN & TEH & GUNUNG & KANCANA \\
KAB.CIANJUR & &
\end{tabular}


memberikan pelatihan kepada bawahannya agar karyawan tersebut dapat melaksanakan tugasnya lebih baik sehingga tujuan perusahaan dapat terealisasi dengan baik Produktivitas kerja merupakan pemanfaatan atau penggunaan sumber daya manusia secara efektif dan efesien. Hal tersebut yang mendorong dan menjadi dasar penulis untuk melakukan penelitian di PT. HK. Waringin Perkebunan Teh Gunung Kancana, dengan judul penelitian ini adalah "Pengaruh Penerapan Strategi Peningkatan Sumber Daya Manusia Terhadap Peningkatan Kualitas Produksi Teh Hijau PT. HK. Waringin Perkebunan Gunung Kancana Kab.Cianjur”.

\section{METODE PENELITIAN}

\section{Tempat dan Waktu Penelitian}

Penelitian ini dilakukan dengan cara langsung terjun ke objek penelitian di PT. HK Waringin Perkebunan Teh Gunung Kancana, yang terletak di Jln. Cilubang, Desa. Cibokor, Kecamatan Cibeber, Kabupaten Cianjur, Pelaksanaan penelitian dilakukan sejak Bulan Februari sampai dengan Mei. Waktu tersebut sudah mencakup penelitian serta penyusunan laporannya.

\section{Populasi dan Sampel \\ Populasi}

Menurut Rianse, dkk (2009), populasi adalah keseluruhan obyek penelitian. Sedangkan menurut Sugiyono (2015), populasi adalah wilayah generalisasi yang terdiri dari suatu obyek/ subyek yang mempunyai kualitas serta karakteristik tertentu yang telah ditetapkan oleh peneliti yang hendak dipelajari dan ditarik sebuah kesimpulan.

Dari paparan di atas dapat disimpulkan bahwa populasi bukan hanya sekedar orang saja, melainkan juga sebuah obyek dan benda-benda alam yang lain, bukan hanya sekedar jumlah populasi dalam penelitian ini adalah 120 Karyawan Dalam penelitian ini penulis mempersempit populasi yaitu jumlah seluruh karyawan sebanyak 120 karyawan dengan menghitung ukuran sampel yang dilakukan dengan menggunakan teknik Slovin menurut Sugiyono (2011:87).

Adapun penelitian ini menggunakan rumus Slovin karena dalam penarikan sampel, jumlahnya harus representative agar hasil penelitian dapat digeneralisasikan dan perhitungannya pun tidak memerlukan tabel jumlah sampel, namun dapat dilakukan dengan rumus dan perhitungan sederhana.

\begin{tabular}{lrrr}
\hline PENGARUH & STRATEGI & PENINGKATAN & ADANG SURYANA, TONI SUYONO \\
KINERJA KARYAWAN & TERHADAP & dan ELMA NURHAFIDAH ISKANDAR \\
PENINGKATAN KUALITAS PRODUKSI TEH & \\
HIJAU DI & PT. & HK. & WARINGIN \\
PERKEBUNAN & TEH & GUNUNG & KANCANA \\
KAB.CIANJUR & &
\end{tabular}


Rumus Slovin untuk menentukan sampel adalah sebagai berikut :

$$
\mathbf{n}=\frac{N}{1+N(e)^{2}}
$$

Keterangan:

$\mathrm{n}=$ Ukuran sampel/jumlah responden

$\mathrm{N}=$ Ukuran populasi

$\mathrm{E}=$ Presentase kelonggaran ketelitian kesalahan pengambilan sampel yang masih bisa ditolerir; $\mathrm{e}=0,1$

Dalam rumus Slovin ada ketentuan sebagai berikut:

Nilai e $=0,1(10 \%)$ untuk populasi dalam jumlah besar

Nilai e $=0,2(20 \%)$ untuk populasi dalam jumlah kecil

Jadi rentang sampel yang dapat diambil dari teknik Solvin adalah antara 10-20 \% dari populasi penelitian.

Jumlah populasi dalam penelitian ini adalah sebanyak 120 karyawan, sehingga presentase kelonggaran yang digunakan adalah $10 \%$ dan hasil perhitungan dapat dibulatkan untuk mencapai kesesuaian. Maka untuk mengetahui sampel penelitian, dengan perhitungan sebgai berikut:

$$
\begin{aligned}
& \mathrm{N}=\frac{120}{1+N e^{2}} \\
& \mathrm{~N}=\frac{120}{\left(1+\left(120 \times 0,05^{2}\right)\right.} \\
& \mathrm{N}=\frac{120}{(1+(120 \times 0,0025)} \\
& \mathrm{N}=\frac{120}{(1+0,3)} \\
& \mathrm{N}=\frac{120}{(1,3)} \\
& \mathrm{N}=93, \text { disesuaikan oleh peneliti menjadi } 100 \text { responden. }
\end{aligned}
$$

Berdasarkan perhitungan diatas sampel yang mejadi responden dalam penelitian ini di sesuaikan menjadi sebanyak 100 orang dari total karyawan PT. HK. Waringin Perkebunan Teh Gunung Kancana, hal ini dilakukan untuk mempermudah dalam pengolahan data dan untuk hasil pengujian yang lebih baik.

\section{Sampel}

Menurut Sugiyono (2015), Sampel adalah suatu bagian dari jumlah dan karakteristik yang dimiliki oleh populasi tersebut. Terdapat 2 (dua) metode yang dapat digunakan untuk menarik sampel dalam sebuah penelitian yang dibuat berdasarkan ada atau tidak adanya peluang (probability dan non-probability).

Penelitian ini dapat dikaitkan dengan subyek atau obyek yang berhubungan langsung dengan Perusahaan, dan SDM. Namun, dengan jumlah populasi yang tidak diketahui secara pasti, maka pengambilan sampelnya secara non probability sampling

\begin{tabular}{lrrr}
\hline PENGARUH & STRATEGI & PENINGKATAN & ADANG SURYANA, TONI SUYONO \\
KINERJA KARYAWAN & TERHADAP & dan ELMA NURHAFIDAH ISKANDAR \\
PENINGKATAN KUALITAS PRODUKSI TEH & \\
HIJAU DI & PT. & HK. & WARINGIN \\
PERKEBUNAN & TEH & GUNUNG & KANCANA \\
KAB.CIANJUR & &
\end{tabular}


dengan teknik quota sampling. Sampling quota adalah sebuah teknik untuk menentukan sampel dari populasi yang mempunyai ciri-ciri tertentu sampai jumlah (kuota) yang diperlukan atau diinginkan (Sugiyono, 2015). Besarnya sampel di penelitian ini adalah 100 orang.

\section{Variabel Penelitian}

Variabel penelitian merupakan suatu atribut atau sifat yang dapat dijadikan nilai dari orang, obyek ataupun kegiatan yang mempunyai variasi tertentu yang ditetapkan oleh peneliti untuk dipelajari dan dapat ditarik sebuah kesimpulan. Dalam penelitian ini yang menjadi variabel penelitian adalah kinerja Karyawan atau Kulitas Produksi teh hijau. Dalam penelitian ini penulis mengoperasionalkan variabel penelitian seperti pada table q. sebagai berikut:

Tabel 1. Operasional Variabel

\begin{tabular}{|c|c|c|c|}
\hline Variabel Penelitian & Konsep Variabel & Indikator & Skala \\
\hline \multirow[t]{3}{*}{$\begin{array}{l}\text { Pengaruh } \\
\text { Karyawan (X1) adalah } \\
\text { hasil kerja yang dapat } \\
\text { dicapai oleh seseorang } \\
\text { atau sekelompok orang } \\
\text { dalam satu organisasi } \\
\text { sesuai dengan tanggung } \\
\text { jawab }\end{array}$} & $\begin{array}{l}\text { 1. Kerja Sama adalah kegiatan } \\
\text { atau usaha yang dilakukan oleh } \\
\text { bebrapa orang untuk mencapai } \\
\text { tujuan bersama. }\end{array}$ & $\begin{array}{l}\text { 1. Tujuan Yang } \\
\text { Sama } \\
\text { 2. Antusiasme } \\
\text { 3. Peran dan } \\
\text { Tanggung } \\
\text { Jawab } \\
\text { 4. Komunikasi } \\
\text { yang Efektif }\end{array}$ & \multirow[t]{3}{*}{$\begin{array}{l}\text { Likert } \\
(1-5) \\
\text { jenis } \\
\text { data } \\
\text { yang di } \\
\text { peroleh } \\
\text { ordinal }\end{array}$} \\
\hline & $\begin{array}{l}\text { 2. Prestasi Kerja adalah hasil yang } \\
\text { dicapai seseorang menurut } \\
\text { ukuran yang berlaku untuk } \\
\text { pekerjaan yang bersangkutan. }\end{array}$ & $\begin{array}{l}\text { 1. Kesetiaan } \\
\text { 2. Penilaiian } \\
\text { Kinerja } \\
\text { 3. Kejujuran } \\
\text { 4. Kedisiplinan } \\
\text { 5. Kreativitas }\end{array}$ & \\
\hline & $\begin{array}{l}\text { 3. Produktivitas adalah sebuah } \\
\text { konsep yang menggambarkan } \\
\text { hubungan antara hasil (jumlah } \\
\text { barang atau jasa yang } \\
\text { diproduksi) }\end{array}$ & $\begin{array}{l}\text { 1. Perbaikan Terus } \\
\text { Menerus } \\
\text { 2. Peningkatan } \\
\text { Mutu hasil } \\
\text { pekerjaan } \\
\text { 3. Tugas pekerjaan } \\
\text { yang menantang } \\
\text { 4. Semangat kerja }\end{array}$ & \\
\hline \multirow[t]{2}{*}{$\begin{array}{l}\text { Kinerja Tenagaa Teknis } \\
\text { (X2) adalah hasil kerja } \\
\text { secara kualitas dan } \\
\text { kuantitas yang dicapai } \\
\text { oleh seorang pegawai } \\
\text { dalam melaksanakan } \\
\text { pekerjaannya }\end{array}$} & $\begin{array}{l}\text { 1. Kompetensi Karyawan adalah } \\
\text { adalah kemampua yang dimiliki } \\
\text { seseorang karyawan dalam } \\
\text { melakukan tugas dan tanggung } \\
\text { jawabnya }\end{array}$ & $\begin{array}{l}\text { 1. Pengetahuan } \\
\text { 2. Keterampilan } \\
\text { 3. Sikap/Atitude }\end{array}$ & \multirow[t]{2}{*}{$\begin{array}{l}\text { Likert } \\
(1-5) \\
\text { jenis } \\
\text { data } \\
\text { yang di } \\
\text { peroleh } \\
\text { ordinal }\end{array}$} \\
\hline & $\begin{array}{l}\text { 2. Kecakapan Tangung Jawab } \\
\text { adaalah kesanggupan seorang }\end{array}$ & $\begin{array}{l}\text { 1. Perbutan Yang } \\
\text { di harapkan }\end{array}$ & \\
\hline
\end{tabular}

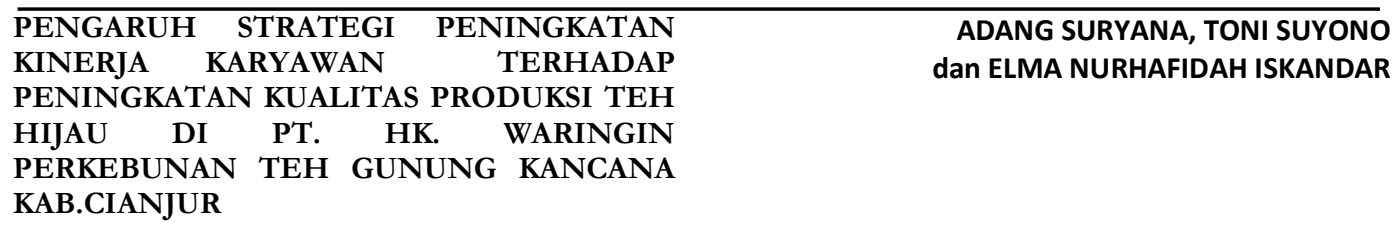




\begin{tabular}{llll}
\hline \multicolumn{1}{c}{ tenaga kerjadalam menyelesaik 2. Perencanaan ke } \\
an tugas dan pekerjaan yang \\
diserahkan kepadanya dengan 3. Selalu Mencoba \\
sebaik-baiknya dan tepat waktu 4. Mengendalikan \\
serta berani membuat risiko diri \\
atas keputusan yang \\
diambilnya.
\end{tabular}

\section{Metode Analisis}

Metode Analisis data adalah suatu metode yang digunakan untuk mengolah hasil penelitian guna memperoleh suatu kesimpulan (Ghozali, 2011). Menurut Sugiyono (2014), analisis data merupakan proses mencari dan menyusun secara sistematis data yang diperoleh dari hasil wawancara, observasi, dan dokumentasi, dengan cara mengorganisasikan data ke dalam kategori, menjabarkan ke dalam unitunit, melakukan sintesa, menyusun ke dalam pola, memilih mana yang penting dan yang akan dipelajari, dan membuat kesimpulan sehingga mudah dipahami oleh diri sendiri dan orang lain. Analisis dalam penelitian ini dilakukan sejak sebelum, saat dan sesudah memasuki lapangan.

\section{Analisis Deskriptif}

Untuk menjawab tujuan penelitian pertama peneliti menggunakan analisis deskriptif kualitatif. Pada Penelitian Kualitatif berupaya memberikan penggambaran secara mendalam tentang situasi atau proses yang diteliti. Menurut Rianse (2009), bahwa Penelitian Kualitatif mengumpulkan dan menggunakan data yang berupa narasi, penuturan, informan, dokumen-dokumen pribadi seperti foto, catatan pribadi, perilaku, gerak tubuh, mimik dan banyak hal lain yang tidak didominasi angka-angka sebagaimana Kuantitatif.

\begin{tabular}{lrrr}
\hline PENGARUH & STRATEGI & PENINGKATAN & ADANG SURYANA, TONI SUYONO \\
KINERJA KARYAWAN & TERHADAP & dan ELMA NURHAFIDAH ISKANDAR \\
PENINGKATAN KUALITAS PRODUKSI TEH & \\
HIJAU DI & PT. & HK. & WARINGIN \\
PERKEBUNAN & TEH GUNUNG & KANCANA & \\
KAB.CIANJUR & &
\end{tabular}




\section{Analisis Kuantitatif}

Analisis kuantitatif merupakan pengukuran data melalui perhitungan ilmiah yang berasal dari sampel yang telah ditentukan yaitu sebanyak 100 orang yang diminta untuk menjawab atas sejumlah pertanyaan tentang survey untuk menentukan frekuensi dan persentase tanggapan responden dengan perhitungan statistik dicari melalui program SPSS.

\section{Analisis Regresi Linear Berganda}

Menurut Ghozali (2006) analisis regresi linear berganda digunakan untuk mengukur pengaruh antara lebih dari satu variable prediktor (Variable bebas) terhadap variable Teriakat (Variable independent). Adapun rumus mantematis dalam penelitian ini adalah sebagi berikut :

$$
Y=a+b_{1} X_{1}+b_{2} X_{2}+e
$$

Keterangan:

$$
\begin{array}{ll}
\mathrm{Y} & =\text { Kulitas Produksi } \\
\mathrm{a} & =\text { Nilai Y bila } \mathrm{X}=0 \text { (constanta). } \\
\mathrm{b}_{1}, \mathrm{~b}_{2} & =\text { Koefisien regresi. } \\
\mathrm{X}_{1}, \mathrm{X}_{2} & =\text { Kinerja Karyawan dan Kinerja Tenaga Teknis } \\
\mathrm{E} & =\text { Standar error }
\end{array}
$$

\section{Uji Instrumen}

\section{Uji Validitas}

Uji validitas digunakan untuk mengukur sah atau validnya suatu kuesioner. Suatu kuesioner dikatakan valid jika pertanyaan pada kuesioner mampu untuk mengungkapkan sesuatu yang akan diukur oleh kuesioner tersebut. Validitas yang digunakan dalam penelitian ini menggambarkan kesesuaian sebuah pengukur data dengan apa yang akan di ukur (Ghozali,2006). Pengujian validitas dilakukan dengan program SPSS 22 (Statistic Product and Service Solution). Item Angket yang diuji dalam uji validitas dikatakan valid apabila rhitung $>$ rtabel pada nilai Signifikan 5\%, sebaliknya apabila rhitung < rtabel pada nilai Signifikan 5\% maka item tersebut dikatakan tidak Valid. Cara menghitung tingkat validitas atau indeks validitas yaitu mencari koefisien product moment dengan angka kasar (Suharsimi Arikuto, 2013:213) :

$$
r_{x y}=\frac{N \sum X Y-\left(\sum X\right)\left(\sum Y\right)}{\left.\sqrt{\left\{N \sum_{X} 2\right.}-\left(\sum_{X} 2\right)\right\}\left(N \sum_{Y} 2-\left(\sum_{Y} 2-\left(\sum_{Y} 2\right)\right\}\right.}
$$

Keterangan :

rxy : Koefisien validitas butir soal

$\mathrm{N} \quad$ : Banyaknya peserta tes

$\mathrm{X} \quad$ : Skor item/ butir soal

Y : Skor total butir soal

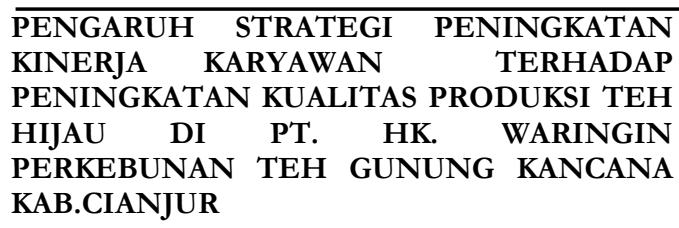




\section{Uji Reabilitas}

Reliabilitas adalah alat untuk mengukur suatu kuesioner yang merupakan indikator dari variabel atau konstruk (Ghazali, 2011). Kuesioner dikatakan reliabel atau handal jika jawaban seseorang terhadap pernyataan adalah konsisten atau stabil dari waktu ke waktu. Adapun cara yang digunakan untuk menguji realibilitas kuesioner dalam penelitian ini menggunakan uji statistik Cronbach's Alpha. Untuk mengetahui kuesioner tersebut sudah reliabel atau tidak kita bisa menggunakan dengan bantuan program SPSS pada komputer.

Tabel. 2. Penilain Kuisioner Reliabel.

\begin{tabular}{ll}
\hline \multicolumn{1}{c}{ Nilai } & \multicolumn{1}{c}{ Keterangan } \\
\hline $\mathrm{r} 11 \leq 0.20$ & Sangat rendah \\
$0.20 \leq \mathrm{r} 11<0.40$ & Rendah \\
$0.40 \leq \mathrm{r} 11<0.70$ & Sedang \\
$0.70 \leq \mathrm{r} 11<0.90$ & Tinggi \\
$0.90 \leq \mathrm{r} 11<1.00$ & Sangat tinggi \\
\hline
\end{tabular}

\section{HASIL DAN PEMBAHASAN}

\section{Karakteristik Responden}

\section{Keadaan Responden}

Identitas Responden dalam satu penelitian sangat berguna sebagai bahan informasi bagi peneliti mengenai latar belakang karyawan. Identitas responden yang digunakan yaitu berupa jenis kelamin, umur, tingkat pendidikan, dan lama bekerja.

\section{Jenis Kelamin Responden}

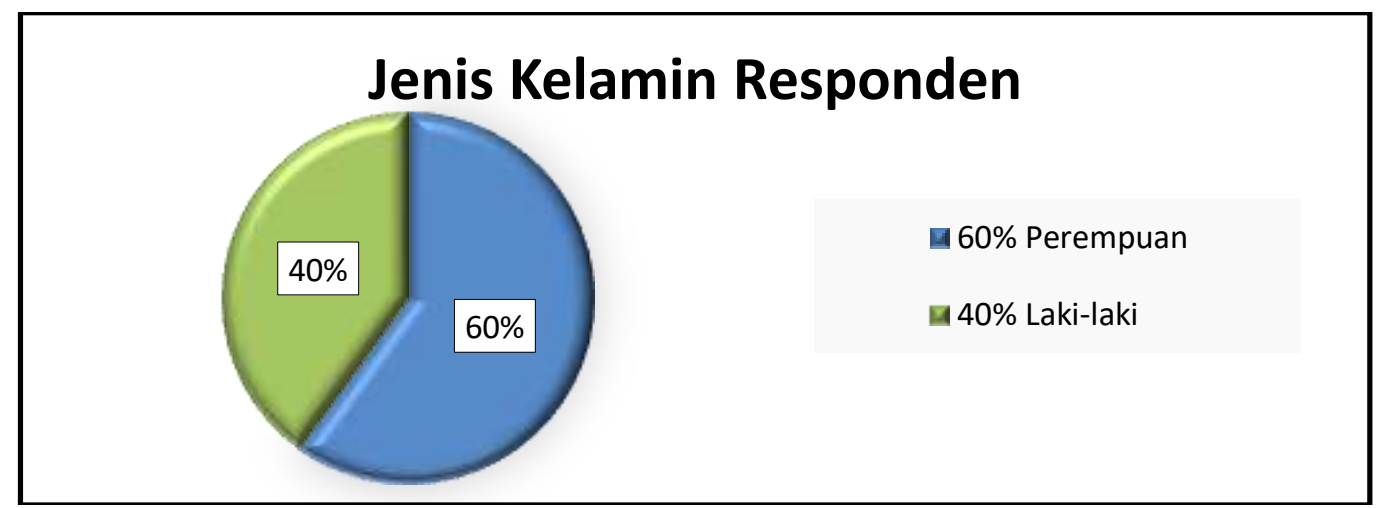

Gambar 1. Persentase Jenis Kelamin.

Dari ke 100 responden yang telah penulis teliti, responden Perempuan memiliki jumlah terbanyak dari pada presponden laki-laki, Persentase responden lailaki yaitu sebesar $40 \%$ sedangkan persentase responden perempuan sebesar $60 \%$. Mayoritasnya yang bekerja di PT. HK. Waringin Perkebunan Teh Gunung Kancana berjenis kelamin Perempuan (Hasil Observasi Lapang, 2021).

\begin{tabular}{lrrr}
\hline PENGARUH & STRATEGI & PENINGKATAN & ADANG SURYANA, TONI SUYONO \\
KINERJA KARYAWAN & TERHADAP & dan ELMA NURHAFIDAH ISKANDAR \\
PENINGKATAN KUALITAS PRODUKSI TEH & \\
HIJAU DI & PT. & HK. & WARINGIN \\
PERKEBUNAN & TEH & GUNUNG & KANCANA \\
KAB.CIANJUR & &
\end{tabular}




\section{Usia Responden}

\section{Usia Responden}

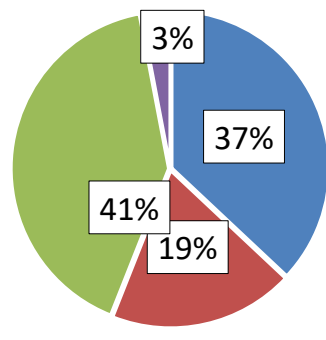

- 37\% 41-50 Tahun

- 19\% 31-40 Tahun

- $41 \%$ Lebih dari 50

- 3\% 21-30 Tahun

Gambar 2. Presentase Usia.

Dari ke 100 responden yang telah penulis teliti, usia lebih dari 50 tahun itu sebesar $41 \%$, usia 41 tahun sampai dengan 50 tahun sebesar $37 \%$, usia 31 tahun sampai dengan 40 tahun sebesar 19\% dan usia 21 tahun sampai dengan 30 tahun sebesar 3\%. Dari data tersebut, dapat ditarik kesimpulan bahwa usia responden dengan usia lebih dari 50 tahun persentase tertinggi, hal itu dikarenakan rendahnya minat atau partisipasi kalangan usia muda yang berperan dalam sektor perkebunan (Hasil Observasi Lapang, 2021).

\section{Tingkat pendidikan Responden}

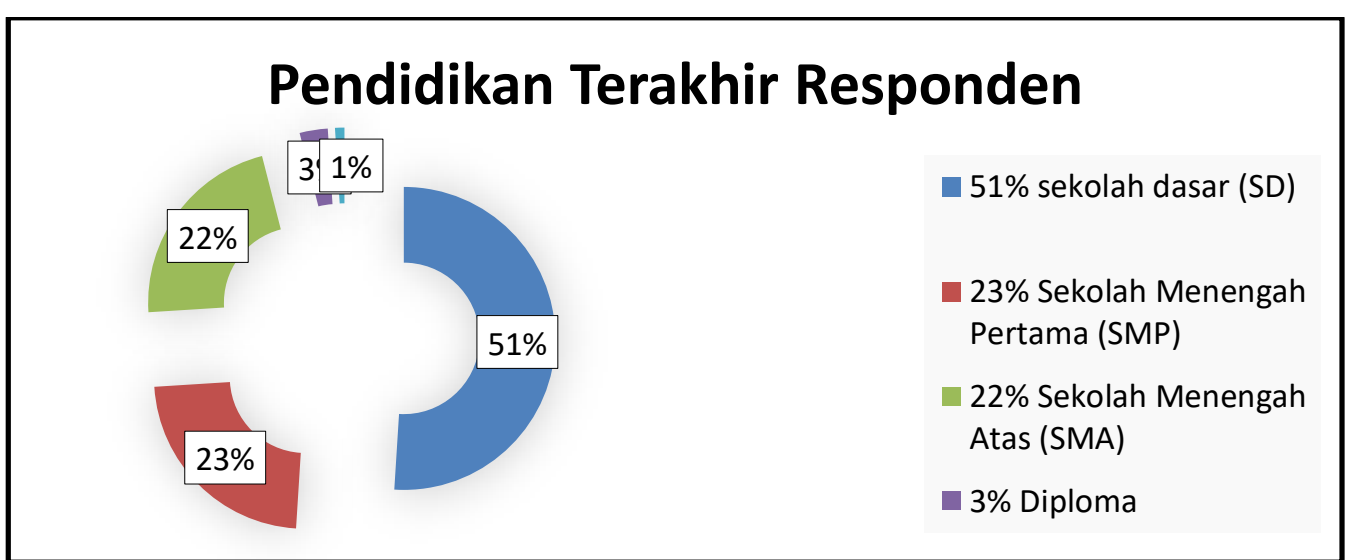

Gambar 3. Presentase Tingkat pendidikan.

Dari ke 100 responden yang telah penulis teliti, tingkat pendidikan SD sebesar 51\%, SMP 23\%, SMA sebesar 22\% dan Diploma dan Sarjana (S1) sebesar 4\%. Dari data tersebut, dapat ditarik kesimpulan bahwa tingkat pendidikan responden SD yaitu sebesar 51\%, hal itu dikarenakan responden yang bekerja mayoritas berpendidikan SD dikarenakan kondisi keluarga dan kesadaran akan pentingnya pendidikan sehingga setelah lulus pendidikan Sekolah Dasar tidak melanjutkan pendidikan ke jengjang selanjutnya. (Hasil Observasi Lapang, 2021)

\begin{tabular}{lrrr}
\hline PENGARUH & STRATEGI & PENINGKATAN & ADANG SURYANA, TONI SUYONO \\
KINERJA KARYAWAN & TERHADAP & dan ELMA NURHAFIDAH ISKANDAR \\
PENINGKATAN KUALITAS PRODUKSI TEH & \\
HIJAU DI & PT. & HK. & WARINGIN \\
PERKEBUNAN & TEH & GUNUNG & KANCANA \\
KAB.CIANJUR & &
\end{tabular}




\section{Lama Bekerja}

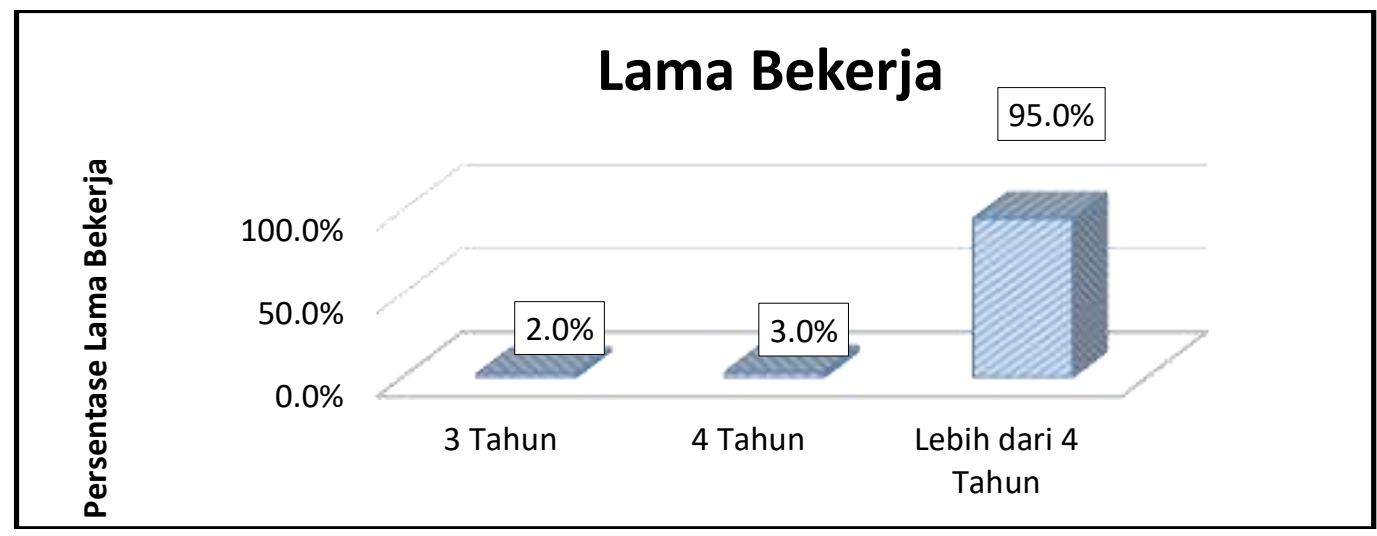

Gambar 4. Persentase Lama Bekerja di PT.HK. Waringin.

Dari ke 100 responden yang telah penulis teliti, lama Bekerja di PT. HK. Waringin dengan lebih dari 4 tahun sebesar 95,0\%, 4 tahun 3,0\%, dan 3 tahun 2,0\%. Dari data tersebut, dapat ditarik kesimpulan bahwa dengan lama waktu bekerja yaitu lebih dari 4 tahun itu persentasenya lebih besar yaitu 95,0\%, hal itu dikarenakan responden sudah sejak lama bekerjasama dengan perusahaan (Hasil Observasi Lapang, 2021).

\section{Pengukuran Instrumen Penelitian}

Instrumen yang di guankan dalam penelitian ini adalah kuesioner. Kuesioner yang diajukan berupa kuesioner tertutup dengan memberikan pertanyaan kepada responden dengan menggunakan skala pengukuran 1 sampai 5 ( skala Likert) yang terdiri atas : 1. Sangat Tidak setuju (STS), 2. Tidak Setuju (TS), 3. Netral (N), 4. Setuju (S), Sangat Setuju (SS). Agar tidak terjadi penyimpangan dan bias dalam jawaban dari responden maka perlu dilakukan uji Instrumen penelitian berupa Uji Validitas dan Reabilitas.

\section{Uji Validitas}

Uji validitas digunakan untuk mengetahui kevalidan angket atau kuesioner dalam mengumpulkan data. Uji validitas digunakan dengan rumus korelasi bivariate person dengan alat bantu program SPSS. Item angket dalm uji validitas dikatakan valid jika rhitung $>$ rtabel pada nilai signifikan 5\% sebaliknya item dinyatakan tidak valid jika rhitung $<$ rtabel pada niai signifikan 5\%. Adapun ringkasan hasil uji validitas sebagaimana data dalam tabel berikut ini.

Uji validitas bertujuan untuk mengetahui valid tidaknya suatu data. Data dinyatakan valid apabila $\mathrm{r}$ hitung $>\mathrm{r}$ tabel, dengan menggunakan rumus $\mathrm{df}=\mathrm{n}-\mathrm{k}$ dengan demikian diperoleh $\mathrm{t}$ tabel sebesar 100-3 = $97=0,1975$

\begin{tabular}{lrrr}
\hline PENGARUH & STRATEGI & PENINGKATAN & ADANG SURYANA, TONI SUYONO \\
KINERJA KARYAWAN & TERHADAP & dan ELMA NURHAFIDAH ISKANDAR \\
PENINGKATAN KUALITAS PRODUKSI TEH & \\
HIJAU DI & PT. & HK. & WARINGIN \\
PERKEBUNAN & TEH & GUNUNG & KANCANA \\
KAB.CIANJUR & &
\end{tabular}


Tabel 3. Uji Validitas Kinerja Karyawan (X1).

\begin{tabular}{cccc}
\hline No Item & r Tabel $\mathbf{5 \%}(\mathbf{1 0 0})$ & r Hitung & Keterangan \\
\hline 1 & 0.1975 & 0.289 & Valid \\
2 & 0.1975 & 0.334 & Valid \\
3 & 0.1975 & 0.346 & Valid \\
4 & 0.1975 & 0.287 & Valid \\
5 & 0.1975 & 0.350 & Valid \\
6 & 0.1975 & 0.346 & Valid \\
7 & 0.1975 & 0.220 & Valid \\
8 & 0.1975 & 0.459 & Valid \\
9 & 0.1975 & 0.287 & Valid \\
10 & 0.1975 & 0.314 & Valid \\
11 & 0.1975 & 0.320 & Valid \\
12 & 0.1975 & 0.468 & Valid \\
13 & 0.1975 & 0.551 & Valid \\
14 & 0.1975 & 0.497 & Valid \\
15 & 0.1975 & 0.448 & Valid \\
16 & 0.1975 & 0.414 & Valid \\
17 & 0.1975 & 0.307 & Valid \\
\hline
\end{tabular}

Sumber : Hasil Pengolahan Data Primer, 2021.

Dari tabel di atas untuk Variabel Kinerja Karyawan (X1) dimana no item pertama dengan pertanyaan "Saya Selalu bersemangat dalam melaksanakan pekerjaan" memiliki nilai $\mathrm{r}$ hitung 0,289> $\mathrm{r}$ tabel 0,1975 dinyatakan valid, No item kedua dengan pertanyaan "Saya selalu memperbaiki peroses dan hasil pekerjaaan apabila terjadi kesalahan" memiliki nilai $\mathrm{r}$ hitung 0,334 > r tabel 0,1975 dinyatakan valid, No item ketiga dengan pertanyaan "Saya mengutamakan target dan kualitas hasil dalam pekerjaan" memiliki nilai $r$ hitung 0,346 > r tabel 0,1975 dinyatakan valid, No item keempat dengan pertanyaan "Saya selalu mengatasi setiap pekerjaan yang menantang" memiliki nilai $r$ hitung $0,287>\mathrm{r}$ tabel 0,1975 dinyatakan valid, No item kelima dengan pertanyaan "Saya menghargai pekerjaan yang menantang" memiliki nilai $\mathrm{r}$ hitung $0,350>\mathrm{r}$ tabel 0,1975 dinyatakan valid, No item keenam dengan pertanyaan "Perusahaan selalu mengingatkan agar saling membantu dalam pekerjaan" memiliki nilai $\mathrm{r}$ hitung $0,346>\mathrm{r}$ tabel 0,1975 dinyatakan valid, No item ketujuh dengan pertanyaan "Saya selalu bersikap Loyal terhadap perusshaan untuk meningkatkan hasil produksi" memiliki nilai $\mathrm{r}$ hitung 0,220 > r tabel 0,1975 dinyatakan valid, No item kedelapan dengan pertanyaan "Perusahaan selalu menilai hasil pekerjaan karyawan untuk meningkatkan hasil produksi" memiliki nilai $\mathrm{r}$ hitung 0,459 > r tabel 0,1975 dinyatakan valid, No item kesembilan dengan pertanyaan "Saya Selalu datang dan menyelesaikan tugas dengan tepat waktu" memiliki nilai $\mathrm{r}$ hitung 0,287 > r tabel 0,1975 dinyatakan valid, No item kesepuluh dengan pertanyaan "Dalam bekerja saya selalu dikejar waktu untuk menyelesaikan pekerjaan" memiliki nilai $\mathrm{r}$ hitung 0,314 > r tabel 0,1975 dinyatakan valid, No item kesebelas dengan pertanyaan "Saya mampu memberikan nilai tambah (added value) yang membedakan kualitas yang saya hasilkan berbeda dengan orang lain" memiliki nilai $r$

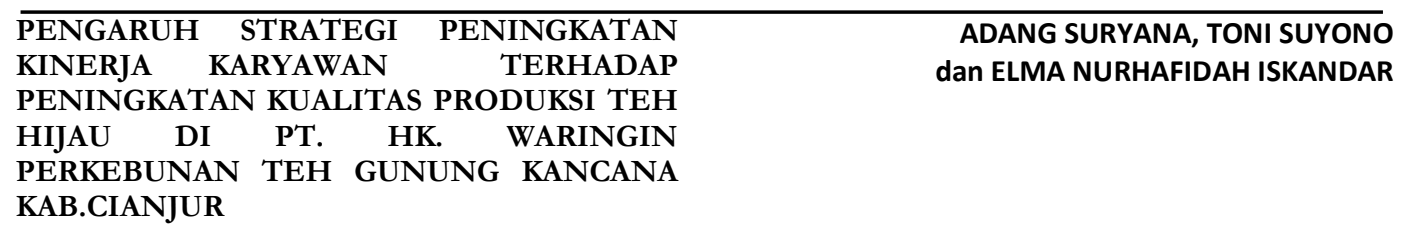


hitung 0,320 > r tabel 0,1975 dinyatakan valid, No item keduabelas dengan pertanyaan "Perusahaan selalu memberikan dorongan agar kerja sama tim bisa berjalan dengan baik" memiliki nilai $\mathrm{r}$ hitung 0,468 > r tabel 0,1975 dinyatakan valid ,No item ketigabelas dengan pertanyaan "Saya selalu penuh Antusias dalam menerima pekerjaaan untuk mencapai tujuan perusahaan" memiliki nilai $\mathrm{r}$ hitung 0,551 > r tabel 0,1975 dinyatakan valid, No item keempatbelas dengan pertanyaan "Saya dapat mempertanggung jawabkan Keputusan yang telah di ambil terhadap pekerjaan yang saya lakukan" memiliki nilai $\mathrm{r}$ hitung $0,497>\mathrm{r}$ tabel 0,1975 dinyatakan valid, No item ke limabelas dengan pertanyaaan "Memiliki kepercayaan diri dan kemampuan yang tinggi dalam membuat keputusan bersama" memiliki nilai $\mathrm{r}$ hitung 0,448 > r tabel 0,1975 dinyatakan valid, No item keenambelas dengan pertanyaan "Saya menunjukan antusiasme terhadap tantangan dan ide baru" memiliki nilai $\mathrm{r}$ hitung $0,414>\mathrm{r}$ tabel 0,1975 dinyatakan valid, No item ketujuhbelas dengan pertanyaan "Saya berkomunikasi secara efektif dengan karyawan dan atasan agar tidak ada miss komunikasi" memiliki nilai $r$ hitung $0,307>\mathrm{r}$ tabel 0,1975 dinyatakan valid. Dari hasil uji Validitas tersebut item No. 13 memiliki nilai tertinggi yaitu 0,551 item tersebut mengenai "Saya selalu penuh Antusias dalam menerima pekerjaaan untuk mencapai tujuan perusahaan", sedangkan item no ke 7 memiliki nilai terendah dari no item lainnya yaitu 0,220 item tersebut mengenai "Saya selalu bersikap Loyal terhadap perusshaan untuk meningkatkan hasil produksi”.

Tabel 4. Uji Validitas Kinerja Tenaga Teknis (X2).

\begin{tabular}{cccc}
\hline No Item & r Tabel $\mathbf{5 \%} \mathbf{( 1 0 0 )}$ & r Hitung & Keterangan \\
\hline 1 & 0.1975 & 0.341 & Valid \\
2 & 0.1975 & 0.465 & Valid \\
3 & 0.1975 & 0.349 & Valid \\
4 & 0.1975 & 0.483 & Valid \\
5 & 0.1975 & 0.529 & Valid \\
6 & 0.1975 & 0.392 & Valid \\
7 & 0.1975 & 0.371 & Valid \\
8 & 0.1975 & 0.258 & Valid \\
9 & 0.1975 & 0.238 & Valid \\
\hline
\end{tabular}

Sumber : Hasil Pengolahan Data Primer, 2021.

Dari tabel di atas untuk Variabel Kinerja Tenaga Teknis (X2) dimana no item pertama dengan pertanyaan "Saya selalu menambah dan meningkatkan pengetahuan dan wawasan untuk mendukung pekerjaan" memiliki nilai $\mathrm{r}$ hitung 0,341 > $\mathrm{r}$ tabel 0,1975 dinyatakan valid, no item kedua dengan pertanyaan "Saya selalu berusaha meningkatkan keterampilan dalam pekerjaan" memiliki nilai $\mathrm{r}$ hitung 0,465 > r tabel 0,1975 dinyatakan valid, no item ketiga dengan pertanyaan "Saya selalu memberikan kontribusi keterampilan terhadap kualitas hasil pekerjaan" memiliki nilai $\mathrm{r}$ hitung 0,349 > r tabel 0,1975 dinyatakan valid, no item keempat dengan pertanyaan "Saya mengutamakan kejujuran dan kedisiplinan dalam bekerja" memiliki nilai $r$ hitung 0,483 > r tabel 0,1975 dinyatakan valid, no item kelima dengan pertanyaan "Saya

\begin{tabular}{lrrr}
\hline PENGARUH & STRATEGI & PENINGKATAN & ADANG SURYANA, TONI SUYONO \\
KINERJA KARYAWAN & TERHADAP & dan ELMA NURHAFIDAH ISKANDAR \\
PENINGKATAN KUALITAS PRODUKSI TEH & \\
HIJAU DI & PT. & HK. & WARINGIN \\
PERKEBUNAN & TEH & GUNUNG & KANCANA \\
KAB.CIANJUR & &
\end{tabular}


bertanggung jawab terhadap kualitas pekerjaan dan kompensasi yang dimiliki” memiliki nilai $\mathrm{r}$ hitung $0,529>\mathrm{r}$ tabel 0,1975 dinyatakan valid, no item keenam dengan pertanyaan "Perusahaan selalu memberikan kesempatan kepada karyawan dan atau tenaga teknis dalam meningkatkan kompetensinya" memiliki nilai $r$ hitung 0,392 > r tabel 0,1975 dinyatakan valid, no item ketujuh dengan pertanyaan "Saya selalu merencanakan pengambilan keputusan yang strategis untuk mencapai target perushaan kedepan" memiliki nilai $\mathrm{r}$ hitung $0,371>\mathrm{r}$ tabel 0,1975 dinyatakan valid, no item kedelapan dengan pertanyaan "Dalam menghadapi kegagalan saya selalu memperbaiki kesalahan agar mencapai target standar kerja" memiliki nilai $\mathrm{r}$ hitung 0,258 > r tabel 0,1975 dinyatakan valid, no item kesembilan dengan pertanyaan "Saya selalu melakukan uji coba untuk meningkatkan kualitas dan produksi" memiliki nilai $r$ hitung 0,238 > r tabel 0,1975 dinyatakan valid. Dari hasil uji Validitas tersebut item No. 05 memiliki nilai tertinggi yaitu 0,529 item tersebut mengenai "Saya bertanggung jawab terhadap kualitas pekerjaan dan kompensasi yang dimiliki", sedangkan item no ke 10 memiliki nilai terendah dari no item lainnya yaitu 0,238 item tersebut mengenai "Saya selalu melakukan uji coba untuk meningkatkan kualitas dan produksi".

Tabel 5. Uji Validitas Kualitas Produksi (Y).

\begin{tabular}{cccc}
\hline No Item & r Tabel $\mathbf{5 \%}(\mathbf{1 0 0})$ & r Hitung & Keterangan \\
\hline 1 & 0.1975 & 0.439 & Valid \\
2 & 0.1975 & 0.659 & Valid \\
3 & 0.1975 & 0.512 & Valid \\
4 & 0.1975 & 0.454 & Valid \\
5 & 0.1975 & 0.433 & Valid \\
6 & 0.1975 & 0.207 & Valid \\
\hline
\end{tabular}

Sumber : Hasil Pengolahan Data Primer, 2021.

Dari tabel di atas untuk Variabel Kualitas Produksi (Y) dimana no item pertama dengan pertanyaan "Perencanaan produksi telah memenuhi pencapaian target perusahaan" memiliki nilai $r$ hitung $0,439>\mathrm{r}$ tabel 0,1975 dinyatakan valid, No item kedua dengan pertanyaan "Perusahaan selalu melakukan koordinasi di dalam dan di luar perusahaan untuk mencapai target perusahaan" memiliki nilai $r$ hitung 0,659 > r tabel 0,1975 dinyatakan valid, no item ketiga dengan pertanyaan "Saya Selalu memperhatikan kerja dan meningkatkan potensi kerja yang telah dimiliki baik atau sangat baik" memiliki nilai $r$ hitung 0,512 > r tabel 0,1975 dinyatakan valid, no item keempat dengan pertanyaan "Saya Selalu melakukan perbaikan standar kerja untuk meningkatkan jumlah hasil produksi" memiliki nilai $\mathrm{r}$ hitung 0,454 $>\mathrm{r}$ tabel 0,1975 dinyatakan valid, no item kelima dengan pertanyaan "Atasan anda menilai kinerja anda sepenuhnya berdasarkan pencapaian target standar kerja" memiliki nilai $\mathrm{r}$ hitung 0,433 > r tabel 0,1975 dinyatakan valid, no item keenam dengan pertanyaan "Atasan terus menerus memantau perkembanagan prestasi anda dalam mencapai standar kerja" memiliki nilai $\mathrm{r}$ hitung 0,207 > r tabel 0,1975 dinyatakan valid. Dari hasil uji validitas tersebut no item ke 02 memiliki nilai tertingggi yaitu 0,659 item

\begin{tabular}{lrrr}
\hline PENGARUH & STRATEGI & PENINGKATAN & ADANG SURYANA, TONI SUYONO \\
KINERJA KARYAWAN & TERHADAP & dan ELMA NURHAFIDAH ISKANDAR \\
PENINGKATAN KUALITAS PRODUKSI TEH & \\
HIJAU DI & PT. & HK. & WARINGIN \\
PERKEBUNAN & TEH & GUNUNG & KANCANA \\
KAB.CIANJUR & &
\end{tabular}


tersebut mengenai "Perusahaan selalu melakukan koordinasi di dalam dan di luar perusahaan untuk mencapai target perusahaan", sedangkan item no ke 6 memiliki nilai terendah dari no item lainnya yaitu 0,207 item tersebut mengenai "Atasan terus menerus memantau perkembanagan prestasi anda dalam mencapai standar kerja".

\section{Uji Reabilitas}

Uji Reabilitas adalah satu nilai yang menunjang konsistensi suatu alat pengukur dalam mengukur gejala yang sama. Uji reabilitas dari setiap konstruk yang di gunakan dalam penelitian ini menggunakan Cronbach's Alpha yang cukup dan dapat di terima adalah bernilai 0,60 sampai 0,70 atau lebih

Dasar pengambilan keputusan uji reabilitas untuk instrumen yang reliabel adalah sebagai berikut:

1. Jika Cronbach's coefficient alpha (a) > 0,6 maka cronbach's alpha acceptable (construct reliable) atau penyataaan dalam kuesioner layak digunakan.

2. Jika Cronbach's coefficient alpha (a) < 0,6 maka cronbach's alpha acceptable (construct reliable) atau penyataaan dalam kuesioner layak digunakan.

Tabel 6. Uji Reliabilitas.

\begin{tabular}{cccc}
\hline Variabel & Cronbach's Alpa & Cronbach's Accaptable & Keterangan \\
\hline X1 & 0.781 & 0.60 & Reliabel \\
X2 & 0.701 & 0.60 & Reliabel \\
Y & 0.713 & 0.60 & Reliabel \\
\hline
\end{tabular}

Hasil uji reliabilitas diperoleh nilai koefisien angket X1 (Kinerja Karyawan) sebesar 0,781, angket X2 ( Kinerja Tenaga Teknis) 0,701, dan angket Y (Kualitas Produksi) sebesar 0,713. Berdasarkan nilai koefisien reliabilitas tersebut dapat disimpulkan bahwa semua angket dalam penelitian ini reliabel atau konsisten karena memiliki nilai $>0,6$ sehingga dapat digunakan sebagai instrumen dalam penelitian dan jawaban responden terhadap pertanyaan-pertanyaan yang digunakan untuk mengukur variabel X1, X2, dan $\mathrm{Y}$ adalah konsisten dan Kontuk dapat dipercaya (reliabel). Berdasarkan tabel diatas dapat disimpulkan bahwa semua variabel dinyatakan Reliable karena lebih besar dari nilai standar yang digunakan/cut off value 0,6 .

\section{Hasil Analisis Penelitian}

\section{Hasil Deskriptif Penelitian}

Adapun cara untuk menentukan kategori penilaian adalah sebagai berikut:

1. Menentukan bobot penialian untuk setiap pilihan jawaban dari responden, dalam hal ini ditentukan berdasarkan skala penialaian yaitu likert scale. Adapun untuk penentuan bobot dapat dilihat parameter perhitungan kuesioner sebagai berikut :

\begin{tabular}{lrrr}
\hline PENGARUH & STRATEGI & PENINGKATAN & ADANG SURYANA, TONI SUYONO \\
KINERJA KARYAWAN & TERHADAP & dan ELMA NURHAFIDAH ISKANDAR \\
PENINGKATAN KUALITAS PRODUKSI TEH & \\
HIJAU DI & PT. & HK. & WARINGIN \\
PERKEBUNAN & TEH & GUNUNG & KANCANA \\
KAB.CIANJUR & &
\end{tabular}


Tabel 7. Parameter Perhitungan Kuesioner.

\begin{tabular}{|c|c|c|}
\hline No & Parameter & Nilai \\
\hline 1 & Jawaban SS & Skor 5 \\
\hline 2 & Jawaban S & Skor 4 \\
\hline 3 & Jawaban N & Skor 3 \\
\hline 4 & Jawaban TS & Skor 2 \\
\hline 5 & Jawaban STS & Skor 1 \\
\hline
\end{tabular}

2. Menghitung skor untuk setiap item pernyataan, yaitu dengan cara mengalikan bobot nilai dengan jumlah frekuensi (jumlah jawaban responden setiap alternatif jawaban tiap item pernyataan).

3. Menghitung nilai terendah dan nilai tertinggi, sebagai berikut:

Skor tertinggi $=$ Bobot nilai tertinggi $\mathrm{x}$ Jumlah responden

Skor tertinggi $=5 \quad$ x $\quad 100=500$

Skor terendah $=$ Bobot nilai terendah $\mathrm{x}$ Jumlah responden

Skor terendah $=1 \quad$ x $\quad 100=100$

4. Untuk memberikan gambaran hasil penelitian setiap variabel. Dengan jumlah skor tertinggi adalah $5 \times 100=500$, jumlah skor terendah adalah $1 \times 100=100$, Skor tersebut akan digunakan untuk mencari bobot pada setiap indikator dari Variabel Kinerja Karyawan, Kinerja Tenaga teknis, dan Kualitas Produksi. Untuk lebih jelasnya, bobot pada indikator - indikator tersebut dapat dilihat pada tabel Berikut:

Tabel 8. Hasil Komulatif Jawaban Responden Variabel X1 (Kinerja Karyawan).

\begin{tabular}{|c|c|c|c|}
\hline No & Item Pertanyaan & $\begin{array}{l}\text { Total } \\
\text { Skor }\end{array}$ & Keterangan \\
\hline 1 & Saya selalu bersemangat dalam melaksanakan pekerjaan. & 488 & Sangat Setuju \\
\hline 2 & $\begin{array}{l}\text { Saya selalu memperbaiki proses dan hasil pekerjaan apabila } \\
\text { terjadi kesalahan. }\end{array}$ & 483 & Sangat Setuju \\
\hline 3 & $\begin{array}{l}\text { Saya mengutamakan target dan kualiatas hasil dalam } \\
\text { pekerjaan. }\end{array}$ & 488 & Sangat Setuju \\
\hline 4 & Saya selalu mengatasi setiap pekerjaan yang menantang. & 482 & Sangat Setuju \\
\hline 5 & Saya menghargai pekerjaan yang menantang. & 485 & Sangat Setuju \\
\hline 6 & $\begin{array}{l}\text { Perusahaan selalu mengingatkan agar saling membantu } \\
\text { dalam pekerjaan. }\end{array}$ & 478 & Sangat Setuju \\
\hline 7 & $\begin{array}{l}\text { Saya selalu bersikap loyalitas terhadap perusahaan untuk } \\
\text { meningkatkan hasil produksi. }\end{array}$ & 460 & Sangat Setuju \\
\hline 8 & $\begin{array}{l}\text { Perusahaan selalu menilai hasil pekerjaan pekerjaan } \\
\text { karyawan untuk miningkatkan hasil produksi. }\end{array}$ & 456 & Sangat Setuju \\
\hline 9 & $\begin{array}{l}\text { Saya selalu datang dan menyelesaikan tugas dengan tepat } \\
\text { waktu. }\end{array}$ & 470 & Sangat Setuju \\
\hline 10 & $\begin{array}{l}\text { Dalam bekerja saya selalu dikejar waktu untuk } \\
\text { menyelesaikan pekerjaan. }\end{array}$ & 470 & Sangat Setuju \\
\hline 11 & $\begin{array}{l}\text { Saya mampu memberikan nilai tambah (Added value) yang } \\
\text { membedakan kualitas yang saya hasilkan berbeda dengan } \\
\text { orang lain. }\end{array}$ & 477 & Sangat Setuju \\
\hline 12 & $\begin{array}{l}\text { Perusahaan selalu memberikan dorongan agar agar } \\
\text { kerjasama tim bisa berjalan dengan baik }\end{array}$ & 458 & Sangat Setuju \\
\hline 13 & Saya selalu penuh antusias dalam menerima pekerjaan & 467 & Sangat Setuju \\
\hline
\end{tabular}

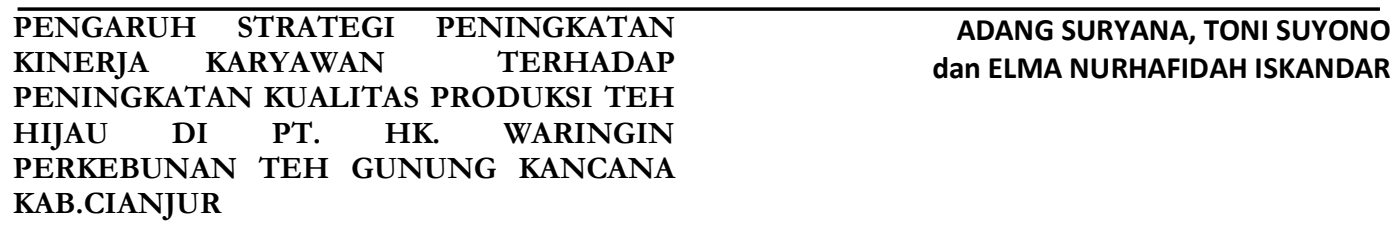


untuk mencapai tujuan perusahaan.

14 Saya dapat mempertanggungjawabkan keputusan yang telah diambil terhadap pekerjaan yang saya lakukan.

$474 \quad$ Sangat Setuju

15 Memiliki kepercayaan diri dan kemampuan yang tinggi dalam membuat keputusan bersama.

475 Sangat Setuju

16 Saya menunjukkan natusiasme terhadap tantangan dan ide baru.

479 Sangat Setuju

17 Saya berkomunikasi secara efektif dengan karyawan dan atasan agar tidak ada miss komunikasi.

484 Sangat Setuju

\begin{tabular}{ccc}
\hline Jumlah & 8074 & Sangat \\
Rata-rata & 474.9 & Setuju \\
\hline
\end{tabular}

Sumber : Data Kuesioner (Diolah,2021).

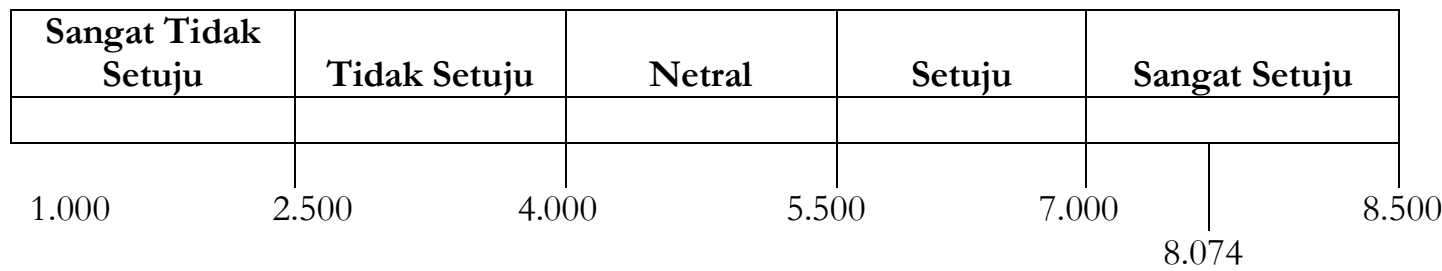

Berdasarkan Tabel 8. di atas Skor total Komulatif Variabel Kinerja Karyawan yaitu sebesar 8.079. dengan jumlah skor tertingi 5 x 17 x $100=8.500$ dan untuk skor terendah yaitu $1 \times 17 \times 100=1.700$. Klasifikasi skor jawaban responden Kinerja Karyawan di gambarkan dalam tahapan bobot skor dengan rentang skor 1.500 sebagai berikut :

Berdasarkan Bobot skor diatas, menunjukan bahwa variabel kinerja karyawan berkontribusi sanggat tinggi untuk mempengaruhi Kualitas Produksi di PT. HK Waringin Perkebunana Teh Gunung Kancana, karena dengan kontribusi sangat tinggi sudah mencerminkan bahwa Perusahaan sangat puas dengan Kinerja Karyawan.

Tabel 9. Hasil Komulatif Jawaban Responden Variabel X2 (Kinerja Tenaga Teknis)

\begin{tabular}{|c|c|c|c|}
\hline No & Item Pertanyaan & $\begin{array}{l}\text { Total } \\
\text { Skor }\end{array}$ & Keterangan \\
\hline 1 & $\begin{array}{l}\text { Saya selalu menambah dan meningkatkan pengatahuan dan } \\
\text { wawasan untuk mendukung pekerjaan. }\end{array}$ & 464 & Sangat Setuju \\
\hline 2 & $\begin{array}{l}\text { Saya selalu berusaha meningkatkan keterampilan dalam } \\
\text { pekerjaan }\end{array}$ & 473 & Sangat Setuju \\
\hline 3 & $\begin{array}{l}\text { Saya selalu memberikan kontribusi keterampilan terhadap } \\
\text { kualitas hasil pekerjaan. }\end{array}$ & 475 & Sangat Setuju \\
\hline 4 & $\begin{array}{l}\text { Saya mengutamakan kejujuran dan kedisiplinan dalam } \\
\text { pekerjaan. }\end{array}$ & 475 & Sangat Setuju \\
\hline 5 & $\begin{array}{l}\text { Saya bertanggungjawab terhadap kualitas pekerjaan dan } \\
\text { kompensasi yang dimiliki. }\end{array}$ & 485 & Sangat Setuju \\
\hline 6 & $\begin{array}{l}\text { Perusahaan selalu memberikan kesempatan kepada } \\
\text { karyawan dan atau tenaga teknis dalam meningkatkan } \\
\text { kompetensinya. }\end{array}$ & 475 & Sangat Setuju \\
\hline 7 & $\begin{array}{l}\text { Saya selalu merencanakan pengambilan keputusan yang } \\
\text { strategis untuk mencapai target perusahaan kedepan. }\end{array}$ & 475 & Sangat Setuju \\
\hline
\end{tabular}

\begin{tabular}{|c|c|}
\hline \multicolumn{2}{|l|}{$\begin{array}{lrl}\text { PENGARUH } & \text { STRATEGI } & \text { PENINGKATAN }\end{array}$} \\
\hline KINERJA KARYAWAN TERHADAP & dan ELMA NURHAFIDAH ISKANDAR \\
\hline PENINGKATAN KUALITAS PRODUKSI TEH & \\
\hline $\begin{array}{lccc}\text { HIJAU DI } & \text { PT. } & \text { HK. } & \text { WARINGIN } \\
\text { PERKEBUNAN } & \text { TEH } & \text { GUNUNG } & \text { KANCANA } \\
\text { KAB.CIANIUR } & \end{array}$ & \\
\hline
\end{tabular}


8 Dalam menghadapi kegagalan saya selalu memperbaiki

kesalahan agar mencapai target standar kerja.

474 Sangat Setuju

9 Saya selalu melakukan uji coba untuk meningkatkan kualitas dan produksi.

$480 \quad$ Sangat Setuju

\begin{tabular}{ccc}
\hline Jumlah & 4276 & Sangat \\
Rata-rata & 475.1 & Setuju \\
\hline
\end{tabular}

Berdasarkan Tabel 9. di atas Skor total Komulatif Variabel Kinerja Tenaga Teknis yaitu sebesar 4.276. dengan jumlah skor tertingi $5 \times 9 \times 100=4.500$ dan untuk skor terendah yaitu $1 \times 9 \times 100=900$. Klasifikasi skor jawaban responden Kinerja Karyawan di gambarkan dalam tahapan bobot skor dengan rentang skor 700 sebagai berikut :

\begin{tabular}{|l|r|r|r|r|}
\hline $\begin{array}{c}\text { Sangat Tidak } \\
\text { Setuju }\end{array}$ & Tidak Setuju & Netral & Setuju & Sangat Setuju \\
\hline & & & & \\
\hline \\
\hline
\end{tabular}

Berdasarkan Bobot skor diatas, menunjukan bahwa variabel kinerja Tenaga Teknis berkontribusi sanggat tinggi untuk mempengaruhi Kualitas Produksi di PT. HK Waringin Perkebunana Teh Gunung Kancana, karena dengan kontribusi sangat tinggi sudah mencerminkan bahwa Perusahaan sangat puas dengan Kinerja Tenaga Teknis.

Tabel 10. Hasil Komulatif Jawaban Responden Variabel Y (Kualitas Produksi).

\begin{tabular}{clcc}
\hline No & \multicolumn{1}{c}{ Item Pertanyaan } & $\begin{array}{c}\text { Total } \\
\text { Skor }\end{array}$ & Keterangan \\
\hline 1 & $\begin{array}{l}\text { Perencanaan produksi telah memenuhi pencapaian target } \\
\text { perusahaan. }\end{array}$ & 468 & Sangat Setuju \\
2 & $\begin{array}{l}\text { Perusahaan selalu melakukan koordinasi di dalam dan di } \\
\text { luar perusahaan untuk mencapai target perusahaan. }\end{array}$ & 471 & Sangat Setuju \\
3 & $\begin{array}{l}\text { Saya selalu memperhatikan kerja dan meningkatkan potensi } \\
\text { kerja yang telah dimiliki baik atau sangat baik. }\end{array}$ & 476 & Sangat Setuju \\
4 & $\begin{array}{l}\text { Saya selalu melakukan perbaikan standar kerja untuk } \\
\text { meningkatkan jumlah hasil produksi. }\end{array}$ & 475 & Sangat Setuju \\
5 & $\begin{array}{l}\text { Atasan Anda menilai kinerja Anda sepenuhnya berdasarkan } \\
\text { pencapaian target standar kerja. }\end{array}$ & 476 & Sangat Setuju \\
Atasan terus menerus memantau perkembangan prestasi \\
Anda dalam mencapai standar kerja.
\end{tabular}

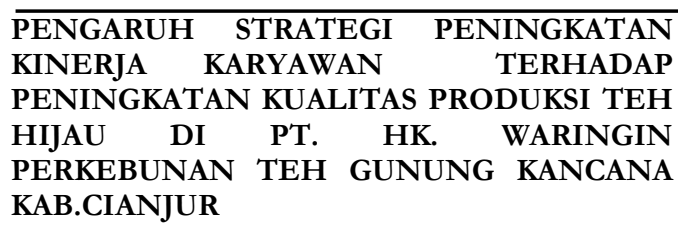


Berdasarkan Tabel 10. di atas Skor total Komulatif Variabel Kualitas Produksi yaitu sebesar 2.838 dengan jumlah skor tertingi $5 \times 6 \times 100=3.000$ dan untuk skor terendah yaitu $1 \times 6 \times 100=600$. Klasifikasi skor jawaban responden Kinerja Karyawan di gambarkan dalam tahapan bobot skor dengan rentang skor 400 sebagai berikut :

\begin{tabular}{|c|c|c|c|c|c|}
\hline $\begin{array}{c}\text { Sangat Tidak } \\
\text { Setuju }\end{array}$ & Tidak Setuju & Netral & Setuju & \multicolumn{2}{|c|}{ Sangat Setuju } \\
\hline & & & & \multicolumn{2}{|c|}{} \\
\hline & & & & & \\
3.000 & 1.400 & 1.800 & 2.200 & 2.600 & 2.838
\end{tabular}

Berdasarkan Bobot skor diatas, menunjukan bahwa variabel Kualitas Produksi berkontribusi sanggat tinggi di PT. HK Waringin Perkebunana Teh Gunung Kancana, namun ada beberapa hal yang harus diperhatikan oleh perusahaan agar Kualitas Produksi tetap meningkat.

Berdasarkan tabel tanggapan responden di atas item indikator dari variabel Kinerja karyawan, Kinerja tenaga teknis, dan Kualitas produksi di rangkum pada tabel berikut :

Tabel 11. Tanggapan Responden Indikator Variabel.

\begin{tabular}{|c|c|c|c|}
\hline No. & Indikator & $\begin{array}{l}\text { Total } \\
\text { Skor }\end{array}$ & Keterangan \\
\hline \multicolumn{4}{|c|}{ Kinerja Karyawan (X1) } \\
\hline 1 & Saya Selalu bersemangat dalam melaksanakan pekerjaan & 488 & Sangat Setuju \\
\hline 2 & $\begin{array}{l}\text { Saya selalu memperbaiki peroses dan hasil pekerjaaan } \\
\text { apabila terjadi kesalahan }\end{array}$ & 483 & Sangat Setuju \\
\hline 3 & $\begin{array}{l}\text { Saya mengutamakan target dan kualitas hasil dalam } \\
\text { pekerjaan }\end{array}$ & 488 & Sangat Setuju \\
\hline 4 & Saya selalu mengatasi setiap pekerjaan yang menantang & 482 & Sangat Setuju \\
\hline 5 & Saya menghargai pekerjaan yang menantang & 485 & Sangat Setuju \\
\hline 6 & $\begin{array}{l}\text { Perusahaan selalu mengingatkan agar saling membantu } \\
\text { dalam pekerjaan }\end{array}$ & 478 & Sangat Setuju \\
\hline 7 & $\begin{array}{l}\text { Saya selalu bersikap Loyal terhadap perusshaan untuk } \\
\text { meningkatkan hasil produksi }\end{array}$ & 460 & Sangat Setuju \\
\hline 8 & $\begin{array}{l}\text { Perusahaan selalu menilai hasil pekerjaan karyawan untuk } \\
\text { meningkatkan hasil produksi }\end{array}$ & 456 & Sangat Setuju \\
\hline 9 & $\begin{array}{l}\text { Saya Selalu datang dan menyelesaikan tugas dengan tepat } \\
\text { waktu }\end{array}$ & 470 & Sangat Setuju \\
\hline 10 & $\begin{array}{l}\text { Dalam bekerja saya selalu dikejar waktu untuk } \\
\text { menyelesaikan pekerjaan }\end{array}$ & 470 & Sangat Setuju \\
\hline 11 & $\begin{array}{l}\text { Saya mampu memberikan nilai tambah (added value) yang } \\
\text { membedakan kualitas yang saya hasilkan berbeda dengan } \\
\text { orang lain }\end{array}$ & 477 & Sangat Setuju \\
\hline
\end{tabular}

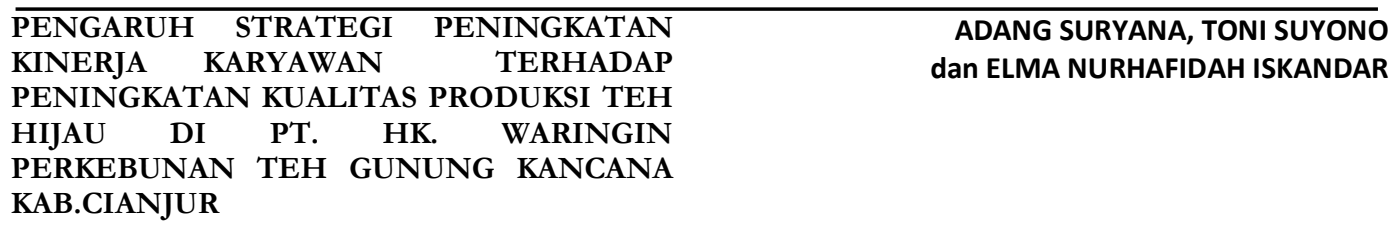


Perusahaan selalu memberikan dorongan agar kerja sama tim bisa berjalan dengan baik Saya selalu penuh Antusias dalam menerima pekerjaaan untuk mencapai tujuan perusahaan

14 Saya dapat mempertanggung jawabkan Keputusan yang telah di ambil terhadap pekerjaan yang saya lakukan

15 Memiliki kepercayaan diri dan kemampuan yang tinggi dalam membuat keputusan bersama

16 Saya menunjukan antusiasme terhadap tantangan dan ide baru

17 Saya berkomunikasi secara efektif dengan karyawan dan atasan agar tidak ada miss komunikasi

\section{Kinerja Tenaga Teknis (X2)}

1 Saya selalu menambah dan meningkatkan pengetahuan dan wawasan untuk mendukung pekerjaan

2 Saya selalu berusaha meningkatkan keterampilan dalam pekerjaan

3 Saya selalu memberikan kontribusi keterampilan terhadap kualitas hasil pekerjaan

4 Saya mengutamakan kejujuran dan kedisiplinan dalam bekerja

5 Saya bertanggung jawab terhadap kualitas pekerjaan dan kompensasi yang dimiliki

Perusahaan selalu memberikan kesempatan kepada

6 karyawan dan atau tenaga teknis dalam meningkatkan kompetensinya

7 Saya selalu merencanakan pengambilan keputusan yang strategis untuk mencapai target perushaan kedepan

8 Dalam menghadapi kegagalan saya selalu memperbaiki kesalahan agar mencapai target standar kerja

9 Saya selalu melakukan uji coba untuk meningkatkan kualitas dan produksi

\section{Kualitas Produksi (Y)}

1 Perencanaan produksi telah memenuhi pencapaian target perusahaan

2 Perusahaan selalu melakukan koordinasi di dalam dan di luar perusahaan untuk mencapai target perusahaan

3 Saya Selalu memperhatikan kerja dan meningkatkan potensi kerja yang telah dimiliki baik atau sangat baik

4 Saya Selalu melakukan perbaikan standar kerja untuk meningkatkan jumlah hasil produksi

5 Atasan anda menilai kinerja anda sepenuhnya berdasarkan pencapaian target standar kerja

6 Atasan terus menerus memantau perkembanagan prestasi anda dalam mencapai standar kerja
Sangat Setuju

$467 \quad$ Sangat Setuju

$474 \quad$ Sangat Setuju

475 Sangat Setuju

479 Sangat Setuju

$484 \quad$ Sangat Setuju

$464 \quad$ Sangat Setuju

473 Sangat Setuju

475 Sangat Setuju

475 Sangat Setuju

485 Sangat Setuju

475 Sangat Setuju

475 Sangat Setuju

$474 \quad$ Sangat Setuju

$480 \quad$ Sangat Setuju

468 Sangat Setuju

$471 \quad$ Sangat Setuju

476 Sangat Setuju

475 Sangat Setuju

476 Sangat Setuju

$472 \quad$ Sangat Setuju

15188 Sangat Setuju

475 Sangat Setuju

\begin{tabular}{|c|c|c|}
\hline \multirow{2}{*}{$\begin{array}{l}\text { PENGARUH } \\
\text { KINERJA }\end{array}$} & STRATEGI & JINGKATAN \\
\hline & KARYAWAN & AP \\
\hline & TAS & \\
\hline DI & HK. & WA \\
\hline $\begin{array}{l}\text { PERKEBUNAN } \\
\text { KAB.CIANJUR }\end{array}$ & EH GUNUN & KA \\
\hline
\end{tabular}


Berdasarkan hasil komulatif di atas jumlah total skor variabel Kinerja Karyawan, Kinerja Tenaga Teknis dan Kualitas Produksi adalah 15188. Dengan jumlah total skor tertinggi $5 \times 32 \times 100=16000$ dan jumlah total skor terrendah adalah 1 × 32 × $100=3200$. Dengan rentang skor 12800 , yang didapat dari perhitungan berikut :

$$
\begin{aligned}
& R=\frac{\text { Skor Maksimal-Skor Minimal }}{5} \\
& R=\frac{16000-3200}{5}=2560
\end{aligned}
$$

Maka skor bobot hasil komulatif kualitas produk, harga dan keputusan pembelian adalah sebagai berikut:

\begin{tabular}{|c|c|c|c|c|c|}
\hline $\begin{array}{c}\text { Sangat Tidak } \\
\text { Setuju }\end{array}$ & Tidak Setuju & Netral & Setuju & \multicolumn{2}{|c|}{ Sangat Setuju } \\
\hline & & & & \multicolumn{2}{|c|}{} \\
\hline \\
$3.200 \quad 5.760 \quad 8.320$ & 10.880 & 13.440 & 16.000
\end{tabular}

15.188

Bobot skor di atas, menunjukkan bahwa variabel kualitas produk berkontribusi sangat tinggi untuk mempengaruhi Kinerja Karyawan dan Kinerja tenaga teknis , namun ada beberapa hal yang harus diperhatikan oleh Perusahaan agar tetap merasa puas saat melakukan keputusan Produksi dan juga selalu memperhatikan masukan dari Karyawan.

\section{PENUTUP}

\section{Kesimpulan}

Berdasarkan uraian pada hasil penelitian, maka dapat ditarik kesimpulan bahwa:

1. Variabel Kinerja Karyawan (X1) berpengaruuh Signifikan terhadap Variabel Kualitas Produksi (Y).

2. Variabel Kinerja Tenaga Teknis (X2) tidak Berpengaruh signifikan terhadap Variabel Kualitas Produksi (Y).

3. Variabel Kinerja Karyawan dan Kinerja Tenaga Teknis, berpengaruh signifikan secara simultan terhadap variabel Kualitas Produksi (Y)

\section{Saran}

Adapun saran yang dapat Penulis berikan sesuai dengan hasil penelitian adalah sebagai berikut :

1. Bagi Perushaan disarankan untuk menyediakan Alat Petik supaya bisa mempermudah karyawan untuk mengefesiensikan waktu agar hasil produksipun lebih meningkat.

2. Bagi Karyawan disarankan agar lebih teliti dalam pengambilan pucuk daun teh agar tidak memberikan efek yang kurang bagus terhadap hasil Produksi.

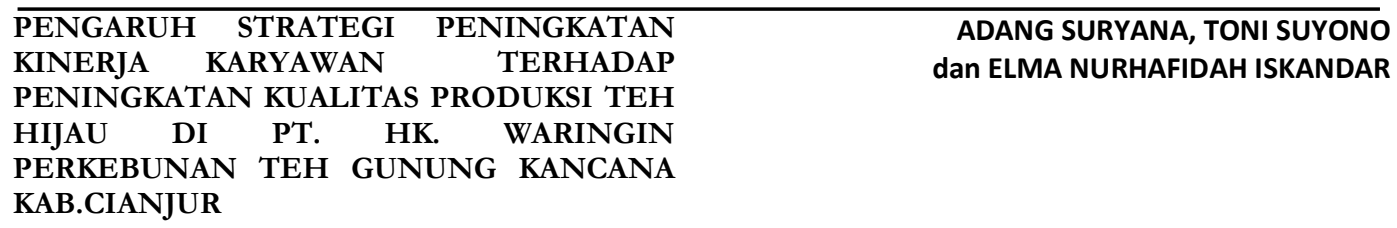


3. Bagi peneliti selanjutnya diharapkan menambah jumlah sampel dan menambah variabel lain yang tidak ada dalam penelitian ini, agar mendapatkan hasil yang lebih maksimal.

\section{DAFTAR PUSTAKA}

Afandi, P. (2018). Manajemen Sumber Daya Manusia (Teori, Konsep dan Indikator). Riau: Zanafa Publishing.

Edison, Emron, dkk. (2016). Manajemen Sumber Daya Manusia. Cetakan Kesatu April 2016. Bandung: Alfabeta.

Ghozali, Imam. (2011). Aplikasi Analisis Multivariate Dengan Program SPSS. Semarang : Badan Penerbit Universitas Diponegoro.

Ghozali. (2016). Aplikasi Analisis Multivariete Dengan Program IBM SPSS. Semarang: Badan Penerbit Universitas Diponegoro.

Kotler, Philip and Kevin Lane Keller. (2016). Marketing Managemen. 15th Edition: Pearson Education,Inc.

Rianse. Abdi. (2009). Metodologi Penelitian Sosial dan Ekonomi (Teori dan Aplikasi). Bandung: Cv. Alfabeta.

Sedarmayanti. (2017). Manajemen Sumber Daya Manusia : Reformasi Birokrasi dan Manajemen Pegawai Negeri Sipil. Bandung: PT. Refika Aditama.

Sugiyono. (2015). Metode Penelitian Kombinasi (Mix Methods). Bandung: Alfabeta.

Sugiyono. (2017). Statistika Untuk Penelitian. Cetakan Ke-28. Januari 2017. Bandung : CV. Alfabeta.

Sugiyono.(2011). Metode Penelitian Kuantitatif, Kualitatif dan R\&D. Bandung: Afabeta.

Sugiyono. (2013). Metodelogi Penelitian Kuantitatif, Kualitatif Dan R\&D. Bandung: Alfabeta.

Sugiyono. (2014). Metode Penelitian Pendidikan Kuantitatif, Kualitatif Dan R\&D. Bandung: Alfabeta.

Sugiyono. (2016). Metode Penelitian Kuantitatif, Kualitatif, dan R\&D. Bandung: Alfabeta.

\begin{tabular}{lrrr}
\hline PENGARUH & STRATEGI & PENINGKATAN & ADANG SURYANA, TONI SUYONO \\
KINERJA KARYAWAN & TERHADAP & dan ELMA NURHAFIDAH ISKANDAR \\
PENINGKATAN KUALITAS PRODUKSI TEH & \\
HIJAU DI & PT. & HK. & WARINGIN \\
PERKEBUNAN & TEH & GUNUNG & KANCANA \\
KAB.CIANJUR & &
\end{tabular}

